\title{
STOP 12: Late-glacial and Holocene development of Lake Rāzna as recorded by biostratigraphy
}

\author{
Sandra Zeimule ${ }^{\mathrm{a}}$, Laimdota Kalniņa ${ }^{\mathrm{a}}$ and Ieva Grudzinska ${ }^{\mathrm{b}}$ \\ ${ }^{\mathrm{a}}$ University of Latvia, Latvia \\ ${ }^{\mathrm{b}}$ Tallinn University of Technology, Estonia
}

The Lake Rāzna is the second largest lake by area and the biggest by volume in Latvia. It is located in the central part of the Latgale Upland (Fig. 12.1A) and occupies the lower part of the extensive glacial depression formed as a result of the activity of the Rāzna glacier tongue over the course of the last deglaciation (Meirons 1975; Zelčs and Markots 2004). The triangular lake narrows in the direction of the former ice flow, i.e. from NW to SE. The lake depression is surrounded by plateau-like hills, morainic hilly massifs, as well as, elementary and composite morainic ridges, whereas the depression itself shows traces of ribbed topography alternating with small depressions (Markots 2013). The complex topography and geological structure of the lake depression, and the character of its shores indicate the the complicated history and diversity of natural processes occurring in various parts of the lake. The sediments of the lake bear evidence of these spatial and temporal developments. The sedimentation environment of the shallow bays of Dūkstigals and Zosnasgals, located in the northern and the north-western part of the lake (Fig. 12.1B), differs to a great extent from that of the deeper part, which mainly contains minerogenic sediments consisting of sand, silt and clay. By contrast, the shallow bays have frequently accumulated organogenic sediments, i.e. gyttja and peat. Earlier investigations of the lake and its adjacent area, carried out by Alksnitis (1998), have mainly been connected with prospection for natural resources, not considering the depositional environment and lake development.
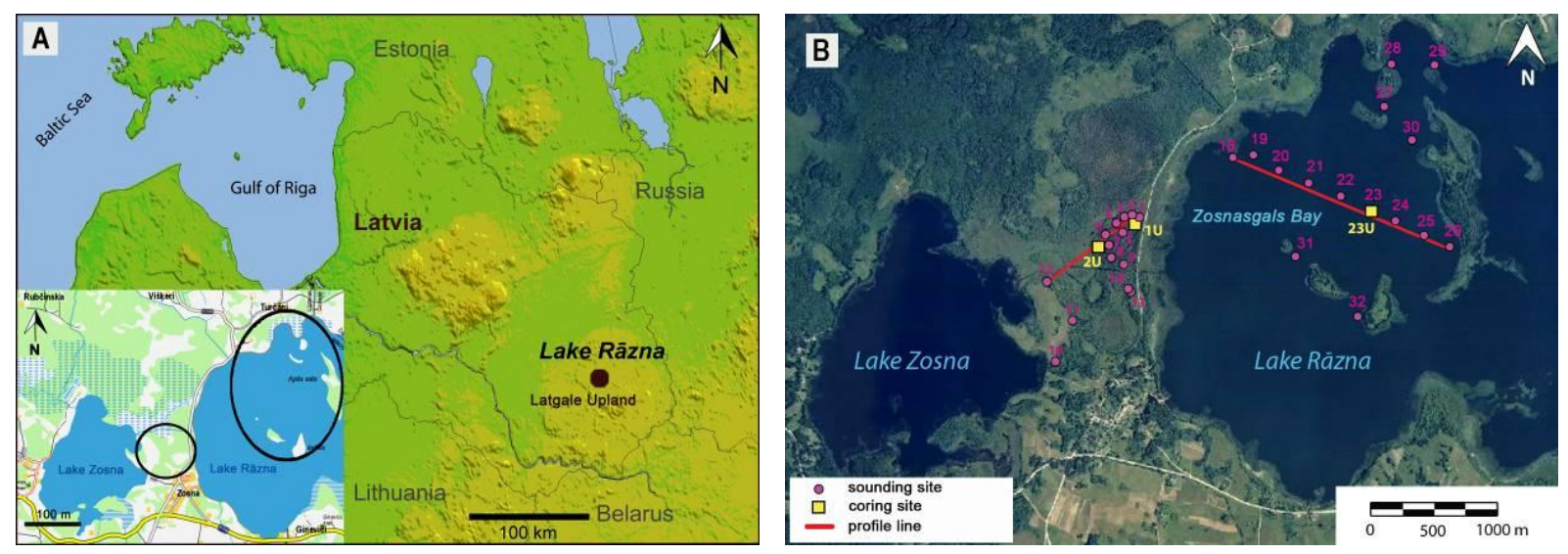

Fig. 12.1. The study area. A. Location of lakes Rāzna and Zosna. B. Location of sounding and coring sites.

The methods applied have been as follows: loss on ignition (LOI), plant macroscopic remain and pollen analyses, as well as identification of the botanical composition of peat, its degree of decomposition and sediment absolute age determination by radiocarbon dating. The results of this interdisciplinary study and their analysis gives an insight into the geological processes and time-transgressive changes in the depositional environment over the course of the lake's development (Zeimule 2013; Zeimule et al. 2014).

The Zosnasgals Bay sediment sequence and the macroscopic plant remains point to a changing depositional environment over the last 12,800 cal yr. According to radiocarbon dating results, the greyish sand at the base of the sediment sequence was deposited at 12800- 
12500 cal yr BP, i.e. in the late Younger Dryas (DR3), as distinguished by Hammarlund et al. (2003). The sand layer was recorded by sounding and coring, which showed that it is distributed in the entire elevated area between the lakes (see Fig. 12.1B for location). Similar processes took place at the same time in Zosnasgals Bay. LOI analysis shows that the content of mineral matter in this layer reaches $95 \%$ (Fig. 12.2A). During this time the vegetation at the lake was rather poor due to the cold and dry climate (Figs. 12.3, 12.4 and 12.5). The only aquatic plant species at the time was the slender-leaved pondweed (Potamogeton filiformis), whereas the seeds of birch (Betula sect. Albae), sedges (Carex sp.) and common bearberry (Arctostaphylos uva-ursi) might have been washed into the lake from the shoreline (Fig. 12.3). This idea is supported by the presence of sandy gyttja accumulated in the middle part, above the layer of sand at approximately 12,500-11,350 cal yr BP. The presence of sand is probably associated with shore erosion. The data from the analysis showed fluctuations in the water level during the Early Holocene (11,350-10,360 cal yr BP). In the eastern part of the elevated area (Fig. 12.1B) a layer of sand was deposited from 11,300 to 11,000 cal yr BP. It became covered by calcareous clay at 11,000-10,500 cal yr BP; this points to a higher water level in Lake Rāzna. Later it dropped again, as indicated by an increase in plant macroscopic remains, suggesting renewed growth of Bryozoa and oogonia in the Zosnasgals Bay sediments.

A


Fig. 12.2. A. Changes in the values of organic, mineral and carbonate matters in sediment composition. B. Agedepth model for the sediment section from core $2 \mathrm{U}$, Zosnasgals Bay. Calibrated ranges of ages and median ages of the samples are plotted against the depth from the sediment surface.

Study of the sediments from core $2 \mathrm{U}$ showed that several aquatic plant species started to grow on the shore of the bay during the period 10,360-8600 cal yr BP (Fig. 12.3). The slenderleaved pondweed was present in the bay during this period. The holly-leaved naiad (Najas marina) remained widespread during the early part of the period, whereas the yellow water lily (Nuphar lutea), the white water lily (Nymphaea alba), cattail (Typha sp.) and bulrush (Scirpus lacustris) appeared at the end of this time interval. A significant presence of oogonia and Bryozoa statoblasts shows that, with some exceptions, the water level in the bay was 
comparatively low.

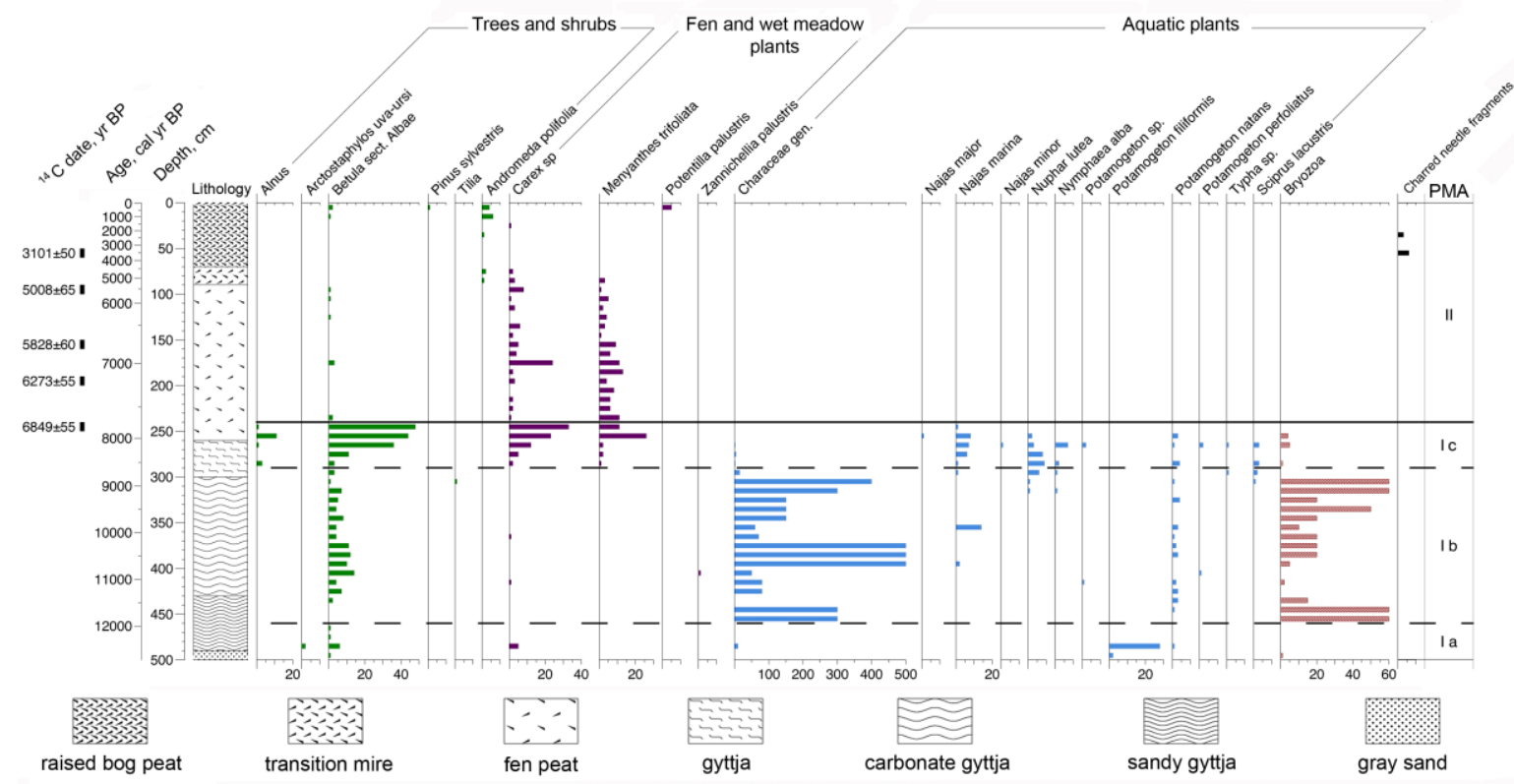

Fig. 12.3. Plant macroscopic remain diagram for thecore $2 \mathrm{U}$ sediment sequence. For location see Fig. 12.1B.

The changes in vegetation are also proven by pollen data reflecting regional vegetation, which leads to the conclusion that these changes were climatically induced. Pinus reaches its maximum $(60 \%)$ at the sediment depth $510 \mathrm{~cm}$, but already in the upper part of pollen zone PAZ ZG1 Pinus and Betula significantly decrease, while the amount of Picea pollen increases (Fig. 12.4). Among the herbs the ruderal plant pollen is dominated by Chenopodium and Artemisia, as well as pasture and meadow plants, mainly represented by Poaceae pollen (Fig. 12.5). The relationship between arboreal (AP) plant and nonarboreal (NAP) plant pollen indicates an open mosaic landscape in the first part of the Early Holocene.

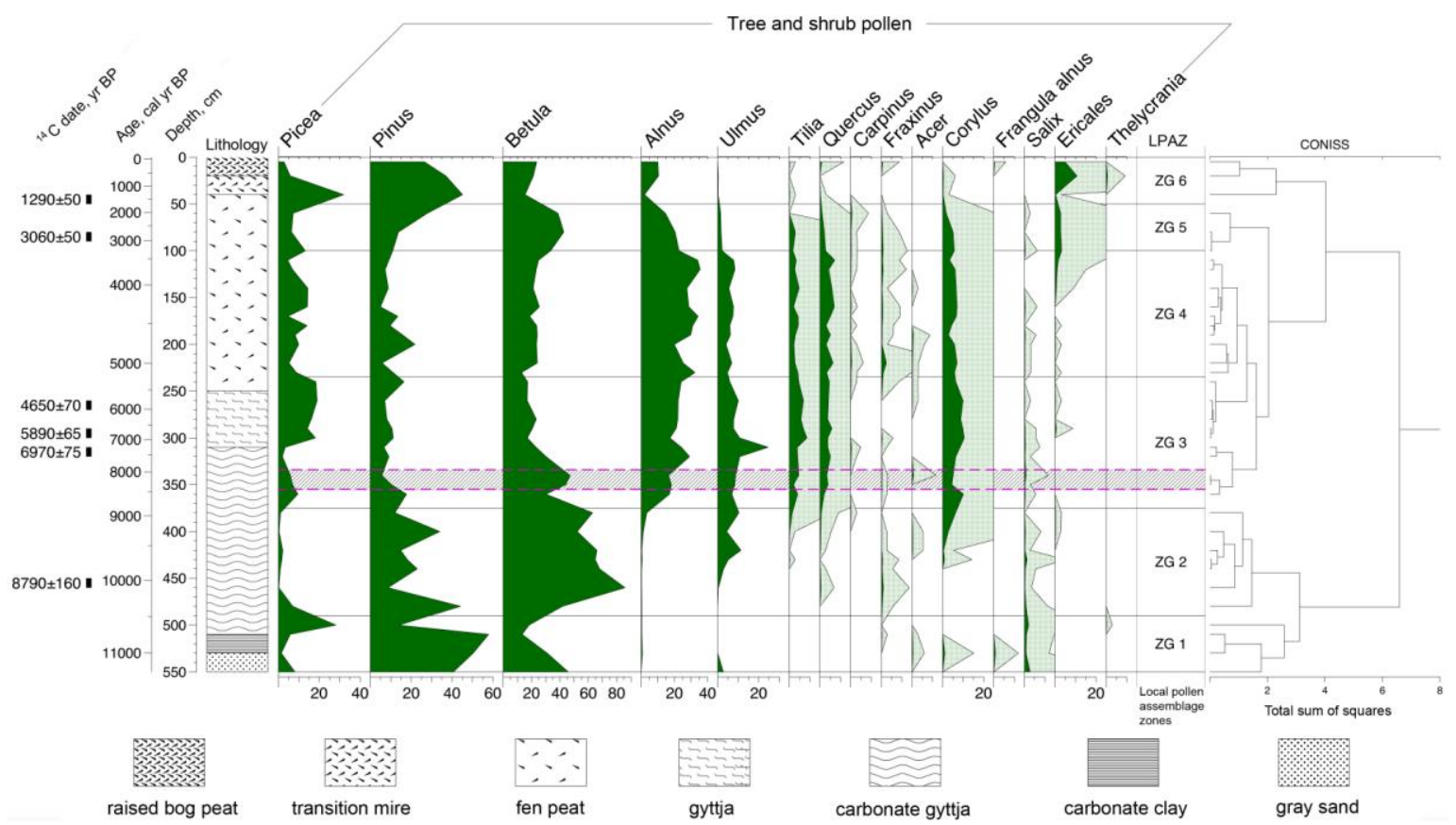

Fig. 12.4. Tree and shrub (AP) pollen percentage diagram from the Zosnasgals $2 \mathrm{U}$ sediment section. For location see Fig. 12.1B. 
During the time corresponding to the Holocene Thermal Maximum, well-decomposed fen-type peat started accumulating between lakes of Rāzna and Zosna. A sharp increase in organic matter in the sediment composition accompanied by more intensive sediment accumulation, is indicated by LOI analysis data (Fig. 12.3A) and by the depth-age model (Fig. 12.3B). This implies warm and dry climatic conditions causing the water level of the lake to drop and the shallowest places in the bay became overgrown. However, not all the shallow-water area in the elevated area separating the lakes was affected simultaneously.

At 8000 cal yr BP, the growth had already spread over the part of the elevated area closer to Lake Zosna, whereas at $5500 \mathrm{cal}$ yr BP it also spread to the part adjacent to Lake Rāzna. The period between 8600 and 7700 cal yr BP is marked by a significant change in the vegetation in the area of Zosnasgals Bay. Apart from lake vegetation, species typical for mires and wetlands, i.e., sedge and bogbean (Menyanthes trifoliata), appeared in a comparatively short time, which proves that the shores of the bay were growing over and the water body was turning into marshland. At the beginning of this time interval lake vegetation still had a somewhat dominant role.

The shore of the overgrowing bay was covered by holly-leaved naiad, yellow and white water lily and slender-leaved pondweed which typically grew next to water lily (Fig. 12.3). However, at the end of the period their number decreased, whereas the sedge and bogbean stands which replaced them indicate a shrinking water surface and excessive plant growth (Gałka et al. 2013). Notably, at 8000 cal yr BP the majority of lakes in Northern Europe were subject to excessive plant growth (Korhola et al. 2010).

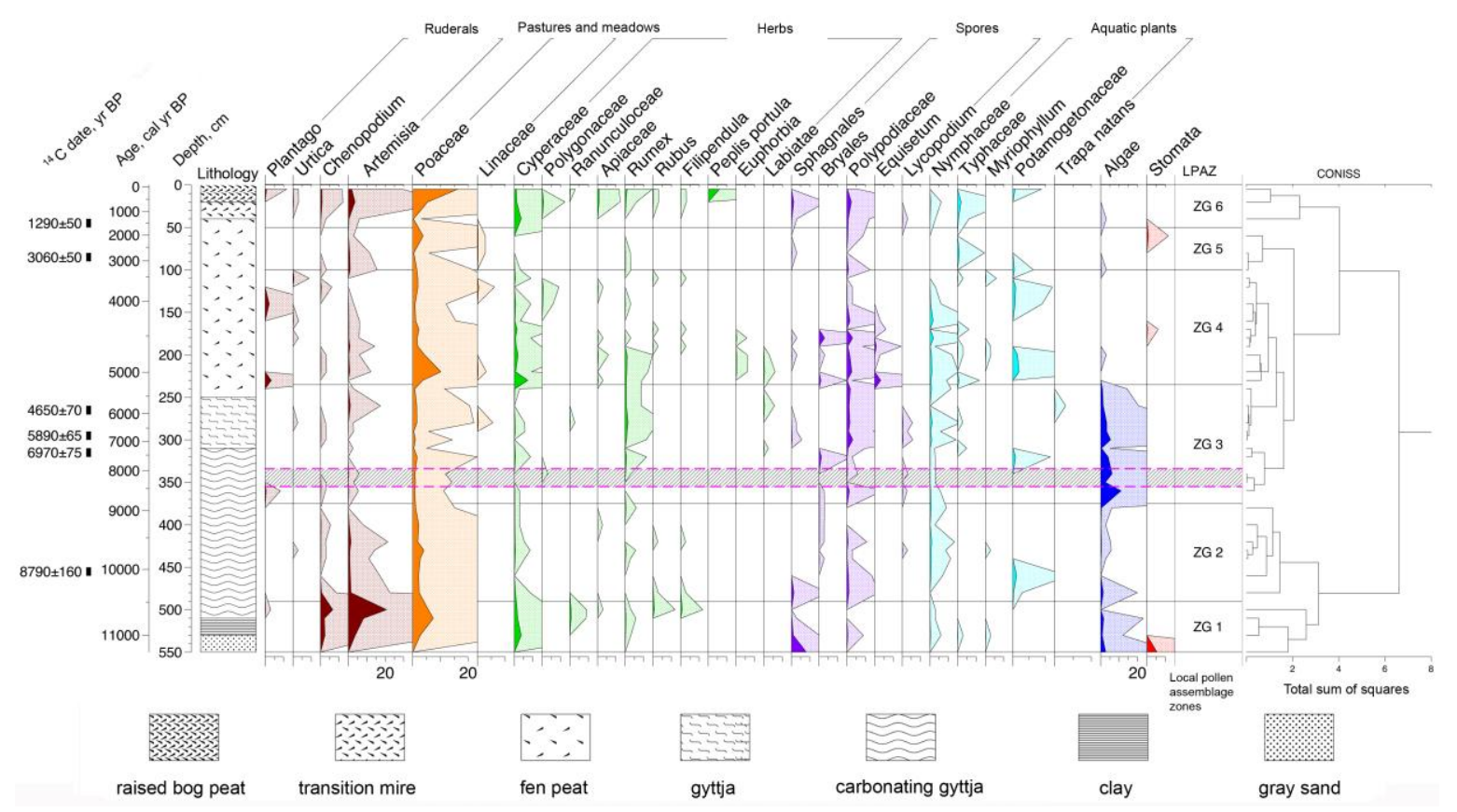

Fig. 12.5. Herb (NAP) pollen percentage diagram for the Zosnasgals $2 \mathrm{U}$ sediment section.

In the middle part of the elevated area (2U) fen conditions persisted from 7700-5330 cal yr BP, whereas in the eastern part (1U) aquatic plants were only becoming less widespread, with oogonia and Bryozoa statoblasts likewise disappearing during this time. At the end of the period propagation of typical marsh and wetland vegetation was common. The waterbody ceased to exist only at $5330 \mathrm{cal}$ yr BP, as demonstrated not only by a change in vegetation, but also by spore-pollen analysis, which indicates algae (typical of an aquatic environment) in the $550-240 \mathrm{~cm}$ deposition interval, whereas above $240 \mathrm{~cm}$ they are no longer present in the 
samples. Therefore, it could be concluded that with the overgrowing of the $1 \mathrm{U}$ area, the area of the palaeolake began to experience change.

The connection between Lake Rāzna and Lake Zosna disappeared, as an isthmus was formed more than $5300 \mathrm{cal} \mathrm{yr} \mathrm{BP}$ ago. Carbonate gyttja indicates increased sedimentation of carbonates in the lake between 9600 and 6500 cal yr BP. During this period the climate gradually became warmer and more carbonates were washed out of the bed of Lake Rāzna and the carbonate-rich glacial deposits around it.

The pollen diagram of the overgrown Zosnasgals Bay indicates two intervals of cold climatic spells, at $8200 \mathrm{cal}$ yr BP and at 3300-2500 cal yr BP, evidenced by a slight increase in mineral matter both in the overgrowing lakebed and in the sediments of the north-western part of Lake Rāzna (Figs. 12.4 and 12.5).

As shown by this study, the composition of the sediments and the changes in composition confirm the hypothesis that Lakes Rāzna and Zosna were part of a single large palaeolake in the late stage of the Late Glacial. With the lowering of the water level and more active overgrowth processes, the palaeolake was gradually divided into two separate lakes. This is also supported by the surface topography and sediment record. The results of the research lead to the conclusion that the palaeolake started overgrowing about 8000 years ago; initially starting with the shallower area separating the two lakes, and the palaeolake ceased to exist, being replaced by two separate lakes, Rāzna and Zosna.

\section{References}

Alksnītis, R. 1998. Pārskats par ezeru sapropę̧u atradņu meklēšanas darbiem Rēzeknes, Preiļu un Jēkabpils rajonos, 2. SIA „Ģeo-Konsultants”, Rīga, Valsts ǵeoloğijas fonds, Inv. No.11875, lpp. 6-141.

Gałka, M., Miotk-Szpiganowicz, G., Goslar, T., Jęśko, M., van der Knaap, W. O., Lamentowicz, M. 2013. Palaeohydrology, fires and vegetation succession in the southern Baltic during the last 7500 years reconstructed from a raised bog based on multi-proxy data. Palaeogeography, Palaeoclimatology, Palaeoecology, 370, 209-221.

Hammarlund, D., Bjorck, S., Buchardt, B., Israelson, C., Thomsen, C. T. 2003. Rapid hydrological changes during the Holocene revealed by stable isotope records of lacustrine carbonates from Lake Igelsjon, southern Sweden. Quaternary Science Reviews, 22, 353-370.

Korhola, A., Ruppel, M., Seppä, H., Väliranta, M., Virtanen, T., Weckström, J. 2010. The importance of northern peatland expansion to the late-Holocene rise of atmospheric methane. Quaternary Science Reviews, 29, 611-617.

Markots, A. 2013. Plakanvirsas pauguru reljefs Austrumlatvijas augstienēs. Latvijas Universitāte, Rīga, 107 lpp.

Meirons, Z. 1975. The relief peculiriaties of the Latgale Elevation and the bordering areas of the East-Latvian Lowland. In: Danilāns, I. (ed.), Problems of Quaternary Geology, 8, Zinātne, Rīga, pp. 48-81 (in Russian, with English summary).

Zeimule, S., Kalniņa, L., Grudzinska, I. 2013. Rāznas ezera Zosnasgala lī̌ca nogulumu paleolimnoloǵiskie pētījumi. In: Grīne, I. (comp.), Latvijas Universitātes 71. zinātniskā konference. Geogrāfija. Geologija. Vides zinātne. Referātu tēzes. Rīga, LU Akadēmiskais apgāds, pp. 291-293.

Zeimule, S. 2013. Rāznas ezera aizaugušā Zosnasgala līča paleolimnologiskā izpēte. Latvijas Universitāte, Rīga, 87 lpp. (Mağistra darbs)

Zelčs, V., Markots, A. 2004. Deglaciation historry of Latvia. In: Ehlers, J., Gibbard, P. L. (eds.), Quaternary Glaciations - Extent and Chronology. Part I: Europe. Developments in Quaternary Science, 2. Elsevier, Amsterdam, pp. 225-243. 

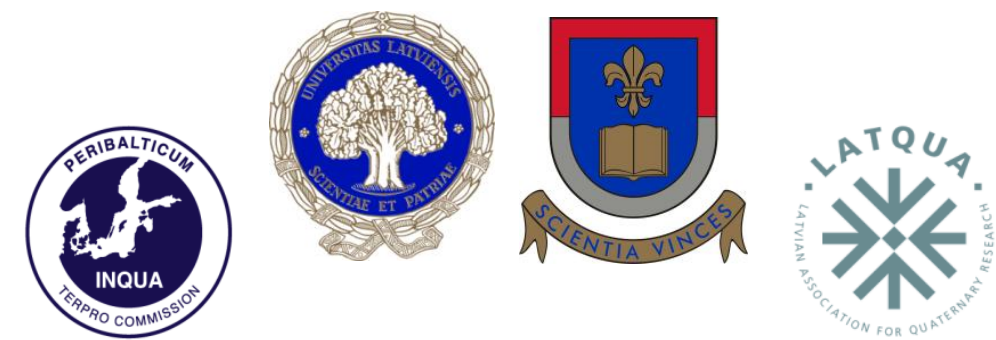

INQUA TERPRO COMMISSION PERIBALTIC WORKING GROUP

UNIVERSITY OF LATVIA

UNIVERSITY OF DAUGAVPILS

LATVIAN ASSOCIATION FOR QUATERNARY RESEARCH

\section{LATE QUATERNARY \\ TERRESTRIAL PROCESSES, SEDIMENTS AND HISTORY: FROM GLACIAL TO POSTGLACIAL ENVIRONMENTS}

EASTERN AND CENTRAL LATVIA

AUGUST 17-22, 2014 


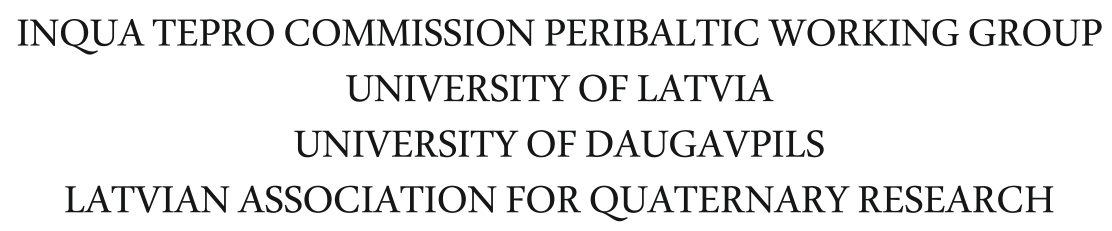

\title{
LATE QUATERNARY \\ TERRESTRIAL PROCESSES, SEDIMENTS AND HISTORY: FROM GLACIAL TO POSTGLACIAL ENVIRONMENTS
}

\author{
EASTERN AND CENTRAL LATVIA
}

AUGUST 16-22, 2014 
Organized by:

University of Latvia

Daugavpils University

Latvian Association for Quaternary Research

INQUA Peribaltic Working Group (INQUA TERPRO Commission)

Organizing committee:

Māris Nartišs (Chair, University of Latvia)

Māris Krievāns (Secretary, University of Latvia)

Aivars Markots (University of Latvia)

Juris Soms (Daugavpils University)

Evija Tērauda (University of Latvia)

Vitālijs Zelčs (University of Latvia)

Contributors:

Ivars Celiņš, Edgars Greiškalns, Ieva Grudzinska, Edyta Kalińska-Nartiša, Laimdota Kalniņa, Jānis Karušs, Māris Krievāns, Kristaps Lamsters, Aivars Markots, Māris Nartišs, Agnis Rečs, Normunds Stivriņš, Juris Soms, Ivars Strautnieks, Santa Strode, Sandra Zeimule, Vitālijs Zelčs

Editors: Vitālijs Zelčs and Māris Nartišs

The English texts of the field guide were revised by Valdis Bērziņš

Recommended reference for this publication:

Zelčs, V. and Nartišs, M. (eds.) 2014. Late Quaternary terrestrial processes, sediments and history: from glacial to postglacial environments. Excursion guide and abstracts of the INQUA Peribaltic Working Group Meeting and field excursion in Eastern and Central Latvia, August 17-22, 2014. University of Latvia, Rīga, 2014, 150 pages.

Sponsored by:

University of Latvia

Layout: Vitālijs Zelčs, Māris Nartišs and Māris Krievāns

ISBN 078-9934-517-60-0

(C) University of Latvia, 2014

This volume is available from:

Faculty of Geography and Earth Sciences

University of Latvia

Rainis Blvd. 19

Rìga, LV1586

Latvia 